\title{
Aging of silicone pressure-sensitive adhesives
}

\author{
Adrian K. Antosik' ${ }^{1}$ Paulina Bednarczyk ${ }^{1} \cdot{\text { Zbigniew } \text { Czech }^{1}}^{1}$
}

Received: 4 November 2016/Accepted: 30 May 2017/Published online: 5 June 2017

(C) The Author(s) 2017. This article is an open access publication

\begin{abstract}
Silicone pressure-sensitive adhesives (Si-PSA) exhibit unique properties, such as high $\mathrm{Si}-\mathrm{O}-\mathrm{Si}$ backbone flexibility, low intermolecular interactions, low surface tension, excellent thermal stability, and high UV transparency, which often explains why silicone PSAs have an impressive performance at high- and lowtemperature extremes, excellent electrical properties, chemical resistance, and outstanding weathering resistance turning them superior compared to organic PSAs. It is well known that due to their unique properties, silicone pressure-sensitive adhesives are materials for special applications. In the present study, we focus on changing the useful properties of the best compositions of silicone pressure-sensitive adhesives in time to verify the impact of aging on them. The influence of time on given silicone pressure-sensitive adhesive tapes and their useful properties is a very important factor for the description of the life-time of potential products based on such compositions. Aging of Si-PSA was carried out for 1 h, 24 h, 7 days, 31 days, and 92 days. The tests did include such properties like adhesion, cohesion (at 20 and $70^{\circ} \mathrm{C}$ ), tack, and yellowness.
\end{abstract}

Keywords Silicone pressure-sensitive adhesives - Self-adhesive tapes · Aging · Silicones

Adrian K. Antosik

adriankrzysztofantosik@gmail.com

1 Institute of Organic Chemical Technology, West Pomeranian University of Technology

Szczecin, ul. Pulaskiego 10, 70-322 Szczecin, Poland 


\section{Introduction}

In the long history of this technology, pressure-sensitive adhesives and tapes as we know them are a fairly recent concept. However, to trace their origins, one needs to study the history of adhesives as a whole, including the many failures and near misses along the way, as well as the fusion of various technologies, which eventually led to their development. Since the dawn of history, people learned of the healing powers of certain leaves and plants. There is archaeological evidence indicating that adhesives have, indeed, been found on primitive tools. Pressuresensitive adhesive (PSA) can be defined as a viscoelastic material, which, in a solvent-free state, remains permanently tacky at room temperature. They are a class of adhesive material that adheres to a substrate under light pressure and can be removed cleanly, on demand, without leaving residues on the substrate. From mechanically point of view, a pressure-sensitive adhesive is a soft, sticky substance [1-3].

Silicones are semi-inorganic polymers (polyorganosiloxanes) that may be fluid, elastomeric, or resinous, depending on the types or organic groups on the silicone atoms and the extent of cross linkage between polymer chains [4, 5]. Silicone pressure-sensitive adhesives (Si-PSA) exhibit unique properties, such as high $\mathrm{Si}-\mathrm{O}-$ $\mathrm{Si}$ backbone flexibility, low intermolecular interactions, low surface tension, excellent thermal stability, and high UV transparency, which often explains why silicone PSAs have an impressive performance at high- and low-temperature extremes, excellent electrical properties, chemical resistance, and outstanding weathering resistance turning them superior compared to organic PSAs. The majority of the traditional silicone PSAs are solvent-borne usually comprised of high-molecular-weight silanol-functional silicone polymers and siloxane resins (MQ); however, there is a growing need to reduce VOC (volatile organic compound) emissions by PSA tapes and labels producers. New silicone PSAs with high solids $(>90 \%)$ or hot-melt types are being introduced to reduce or eliminate VOC emissions and possibly provide properties to extend the use of these materials to new applications. In addition, the desire for more energy-efficient chemistries is driving further development of addition-curing silicone PSAs that can be cured below $100{ }^{\circ} \mathrm{C}$ rather than at the approximate $150{ }^{\circ} \mathrm{C}$ required for peroxide-curing types [4, 6-8]. The crosslinking of silicone PSAs with methyl or/and phenyl groups can be achieved thermally between 120 and $150{ }^{\circ} \mathrm{C}$ by an organic peroxide. The most common reactive thermal crosslinkers are benzoyl peroxide (BPO) and dichlorobenzoyl peroxide (DClBPO). They allow the control of the crosslinking reaction by adjusting the peroxide, which determines the degree of crosslinking of the adhesive composition [5, 9]. It is well known that silicone pressure-sensitives are being used for special applications. Since the year 2000, there has been much interest in new applications for silicone PSAs, especially for medical and industrial tapes. The foregoing examples describe the growing range of potential commercial applications where silicone PSAs are being used and exploited [4, 6, 10].

The design and development of new, tailor-made, novel silicone pressuresensitive adhesives, which can cope with both the technical and ecological demands, 
is, therefore, a continuing challenge for industrial research and development. Progress in the coating technology and the development of improved resistance to aging of Si-PSA will open the door for new applications [11].

The goal of this work was to investigate the influence of time on given silicone pressure-sensitive adhesive tapes and their useful properties. The aging of Si-PSA measurements was carried out after 1 h, 24 h, 7 days, 31 days, and 92 days. The tests include such properties like adhesion, cohesion (at 20 and $70{ }^{\circ} \mathrm{C}$ ), tack, and yellowness.

\section{Experimental}

\section{Materials}

In the presented paper, commercial silicone adhesives were used (acronym: PSA 590, Q2-7566), which are products of Momentive (USA) and Dow Corning (USA). Dichlorobenzoyl peroxide (DClBPO) from Peroxid-Chemie (Germany) was used as a crosslinking agent.

\section{Preparation of silicone pressure-sensitive adhesives tape}

The silicone pressure-sensitive adhesive Q2-7566 (Dow Corning) and the crosslinking agent [1.5 wt\% 2,4-dichlorobenzoyl (DClBPO) peroxide according to polymer content] were mixed to obtain a homogenous organic composition containing $50 \mathrm{wt} \%$ polymer. Subsequently, the PSA was coated with a coating speed of $5 \mathrm{~cm} / \mathrm{s}$ on a $50 \mu \mathrm{m}$-thick polyester film and dried for $10 \mathrm{~min}$ at $110{ }^{\circ} \mathrm{C}$ in drying channel. The self-adhesive layers prepared in this way were secured on a $36 \mu \mathrm{m}$-thick polyester film yielding one-side tapes. These were used for further tests, i.e., adhesion, cohesion, tack, and yellowness index. To study the aging process of silicone pressure-sensitive adhesives, all measurements were carried out after 1 h, 24 h, 7 days, 31 days, and 92 days. In the same way, tapes were prepared using the silicone pressure-sensitive adhesive PSA 590 (Momentive) and tested.

\section{Methods}

The peel adhesion of silicone pressure-sensitive adhesives was tested using a Zwick-Roell Z1 machine according to the international standard Association des Fabricants Europeens de Rubans Auto-Adhesifs (AFERA) 4001 procedures. A sample of PSA-coated material 1 inch (ca. $2.5 \mathrm{~cm}$ ) wide and about 5 inch (ca. $12.7 \mathrm{~cm}$ ) long was bonded to a horizontal target substrate surface consisting of a clean steel test plate providing at least $15 \mathrm{~cm}^{2}$ firm contact. A $2 \mathrm{~kg}$ hard rubber roller was used to apply the strip. The free end of the coated strip was doubled back nearly touching itself, so that the angle of removal would be $180^{\circ}$. The free end was attached to the adhesion tester scale. The steel test plate was clamped in the jaws of a tensile testing machine, which was capable of moving the plate away from the scale at a constant rate of $300 \mathrm{~mm} / \mathrm{min}$. The scale reading in Newton [N] was 
recorded as the tape was peeled from the steel surface. The data were reported as the average of the range of numbers observed during the test. The given result was an arithmetic average of three specimens [3].

The tack of PSA was measured using a Zwick-Roell Z1 machine according to the international standard Association des Fabricants Europeens de Rubans AutoAdhesifs (AFERA) 4015 procedures. The joint is composed of a rigid layer (steel plate) and flexible layer (PSA tape), which was peeled off the plate at an angle of $90^{\circ}$ at $300 \mathrm{~mm} / \mathrm{min}$. The contact surface of the adhesive layer on the substrate was $5 \mathrm{~cm}^{2}(2.5 \mathrm{~cm} \times 2 \mathrm{~cm})[1,12]$.

The shear strength (cohesion) test of PSA was performed according to the method of Fédération Internationale des Fabricants et Transformateurs d'adhesifs et thermocollants sur papiers et autres support (FINAT) FTM 8. The PSA tape was adhered to steel plates and loaded with $1 \mathrm{~kg}$ weight. The contact surface of the adhesive layer on the substrate was $6.25 \mathrm{~cm}^{2}(2.5 \mathrm{~cm} \times 2.5 \mathrm{~cm})$. Samples of the adhesive tape were mounted in a machine designed at the Laboratory for Adhesives and Self-adhesive Materials of the West Pomeranian University of Technology in Szczecin, which enables an automatic time reading of the shear strength crack. The shear strength was tested at 20 and $70{ }^{\circ} \mathrm{C}$ [12].

The shrinkage presents the percentage or millimetre change of dimensions of the PVC or PET film coated with PSA after crosslinking and attached to the glass after keeping it 8 weeks at a temperature of $70{ }^{\circ} \mathrm{C}$. A shrinkage larger than $0.5 \%$ or larger than $0.5 \mathrm{~mm}$ exceeds the permissible shrinkage [13-17].

Pressure-sensitive adhesives have the undesirable feature of yellow discoloration, aesthetically unacceptable to consumers and thus impractical for many applications (Strait et al. [23]). Yellowness index (YI) is often used to determine the color change of the material, due to exposure to atmospheric agents (in conditions natural or artificial). Visually, yellowness of the samples is associated with dirty or the general product degradation by factors such as light, chemical, and treatment process. Yellowness index is primarily used to measure these types of aging degradation using a spectrophotometer. Yellowness index (YI) was measured using a 3 NH NR20XE colorimeter. The Yellowness Index is a number calculated from spectrophotometric data that describe the change in color of a test sample from clear or white to yellow. This test was used to evaluate the color change in an adhesive layer caused by external exposure [18-23].

\section{Results and discussion}

To create one-side tapes based on silicone pressure-sensitive adhesives, compositions with the best physical properties such as adhesion (for different substrates), tack, cohesion, and adhesion-cohesive balance have been selected. The useful properties of Si-PSA obtained in this way were collected in Table $1[12,24]$.

Increasing of time did affect the aging properties of silicon pressure-sensitive adhesives tape. This effect is presented in Tables 2 and 3 and Fig. 1, respectively, as a change in time of the useful typical properties (adhesion, cohesion, and tack), yellowness index, and shrinkage. 
Table 1 Useful typical properties of silicone pressure-sensitive adhesives tape

\begin{tabular}{|c|c|c|c|c|c|}
\hline \multirow[t]{2}{*}{ Sample } & \multirow[t]{2}{*}{ Adhesion $(\mathrm{N} / 25 \mathrm{~mm})$} & \multicolumn{2}{|c|}{ Cohesion (h) } & \multirow{2}{*}{$\begin{array}{l}\text { Maximum work } \\
\text { temperature }\left({ }^{\circ} \mathrm{C}\right)\end{array}$} & \multirow[t]{2}{*}{ Tack $(N$} \\
\hline & & $20^{\circ} \mathrm{C}$ & $70^{\circ} \mathrm{C}$ & & \\
\hline PSA 590 & 13.7 & $>72$ & $>72$ & 154.2 & 8.3 \\
\hline Q2-7566 & 12.5 & $>72$ & $>72$ & 133.2 & 9.6 \\
\hline
\end{tabular}

Table 2 Influence of time on the useful properties of silicone pressure-sensitive adhesive Q2-7566

\begin{tabular}{lclllr}
\hline Time & Adhesion $(N / 25 \mathrm{~mm})$ & \multicolumn{2}{l}{ Cohesion $(\mathrm{h})$} & YI & Tack $(N)$ \\
\cline { 3 - 5 } & & $20{ }^{\circ} \mathrm{C}$ & $70{ }^{\circ} \mathrm{C}$ & & \\
\hline 1 (h) & 10.6 & $>72$ & $>72$ & 0.330 & 10.2 \\
24 (h) & 9.57 & $>72$ & $>72$ & 1.527 & 9.5 \\
7 (day) & 9.31 & $>72$ & $>72$ & 1.840 & 8.5 \\
1 (month) & 8.36 & $>72$ & $>72$ & 2.591 & 7.9 \\
\hline
\end{tabular}

Table 3 Influence of time on the useful properties of the silicone pressure-sensitive adhesive PSA 590

\begin{tabular}{llllll}
\hline Time & Adhesion $(N / 25 \mathrm{~mm})$ & \multicolumn{2}{l}{ Cohesion $(\mathrm{h})$} & YI & Tack $(N)$ \\
\cline { 3 - 5 } & & $20{ }^{\circ} \mathrm{C}$ & $70{ }^{\circ} \mathrm{C}$ & & \\
\hline 1 (h) & 10.4 & $>72$ & $>72$ & 0.526 & 10.3 \\
24 (h) & 10.2 & $>72$ & $>72$ & 1.835 & 9.1 \\
7 (day) & 9.9 & $>72$ & $>72$ & 1.937 & 8.3 \\
1 (month) & 9.0 & $>72$ & $>72$ & 2.653 & 8.0 \\
\hline
\end{tabular}

Along with the aging of silicone pressure-sensitive adhesives tape, a decline of the adhesive film properties such as tack and adhesion was observed. The compositions being tested showed excellent properties of cohesion. There was no deterioration in Si-PSA cohesion at 20 and $70{ }^{\circ} \mathrm{C}$ after month duration of the tests. It is generally accepted that one-sided adhesive tapes must meet basic properties like adhesion $>10 \mathrm{~N} / 25 \mathrm{~mm}$; tack $>8 \mathrm{~N} / 25 \mathrm{~mm}$; cohesion $>72 \mathrm{~h}$ [1]. Tapes after 1 month aging time still show good performance. Pressure-sensitive adhesives thermal decay on an untied and untainted basis often have yellowness indices of about 4 or lower. Preferably, the yellowness index should be about 1.5 or lower. Some samples of adhesives showed low yellowing indexes, which slightly increased over time. The PSA 590 adhesive exhibits a higher degree of yellowing than Q27566. 


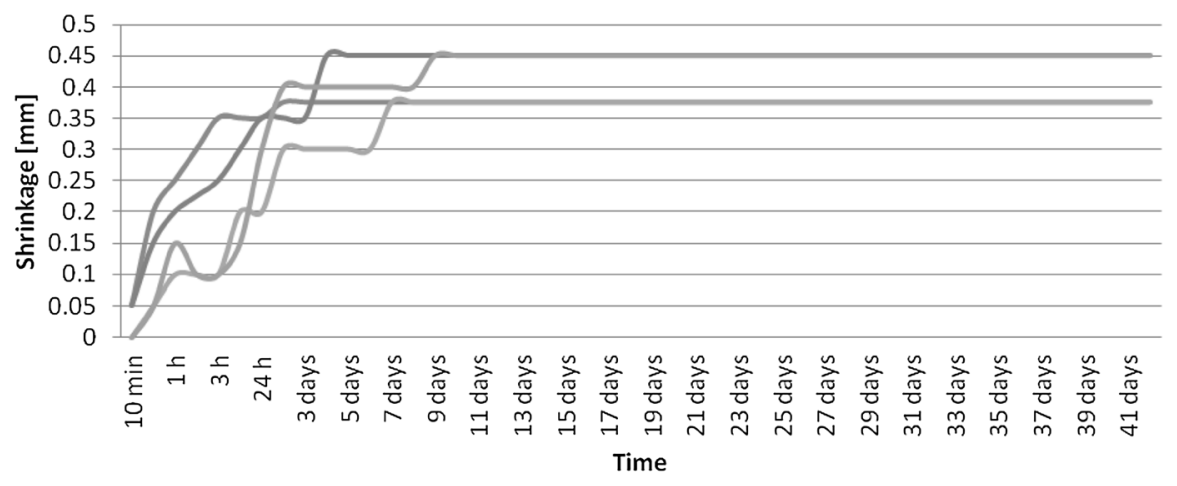

Q2-7566-PVC Q Q2-7566-PET -PSA 590 - PVC PSA 590 - PET

Fig. 1 Shrinkage of Si-PSA vs. time

With a longer aging of the silicone pressure-sensitive adhesives, an increasing shrinkage (up to 9 days after start of measurements) was observed. After this time, the shrinkage level was stabilized and there was no more deterioration for all SiPSA compositions. Both adhesive compositions on PVC-film exhibited a higher shrinkage than compositions on PET film, respectively, 0.35 and $0.45 \mathrm{~mm}$ (Fig. 1).

\section{Conclusions}

In this work, aging tests were carried out for selected adhesive compositions. The compositions tested showed excellent properties. With increasing aging of the silicone pressure-sensitive adhesives, low adhesion and less tack developed; slightly increasing yellowness index; increasing shrinkage within the first few days; and after that time stabilization occurred. There was no effect of aging on the cohesion of adhesives films at 20 and $70{ }^{\circ} \mathrm{C}$. It is well known that silicone adhesives are products of special use. It is generally accepted that one-sided adhesive tape must meet basic properties like adhesion $>10 \mathrm{~N} / 25 \mathrm{~mm}$, tack $>8 \mathrm{~N} / 25 \mathrm{~mm}$, and cohesion $>72 \mathrm{~h}$ [1]. Tapes having been exposed to an aging procedure of 1 month still showed good performance.

Open Access This article is distributed under the terms of the Creative Commons Attribution 4.0 International License (http://creativecommons.org/licenses/by/4.0/), which permits unrestricted use, distribution, and reproduction in any medium, provided you give appropriate credit to the original author(s) and the source, provide a link to the Creative Commons license, and indicate if changes were made.

\section{References}

1. Antosik AK, Bednarczyk P, Czech Z (2015) Jednostronnie klejące taśmy na bazie samoprzylepnych klejów silikonowych-dobór najlepszej kompozycji. Chemik 69:95-97

2. Khan I, Poh BT (2011) Natural rubber-based pressure-sensitive adhesives: a review. J Polym Enviro. doi:10.1007/s10924-011-0299-z 
3. Wilpiszewska K, Czech Z (2014) Citric acid modified potato starch films containing microcrystalline cellulose reinforcement-properties and application. Starch. doi:10.1002/star.201300093

4. Anderson GL, Stanley S, Young GL, Brown RA, Evans KB, Wurth LA (2010) The effects of silicone contamination on bond performance of various bond systems. J Adhes. doi:10.1080/00218464.2010. 529380

5. Benedek I (2006) Developments in pressure-sensitive products. Taylor \& Francis a CRC Press Book, USA

6. Czech Z, Kurzawa R (2007) Acrylic pressure-sensitive adhesive for transdermal drug delivery systems. J Appl Polym Sci. doi:10.1002/app.26751

7. Sun F, Hu Y, Du H-G (2012) Synthesis and characterization of MQ silicone resins. J Appl Polym Sci. doi:10.1002/app.35194

8. Tolia G, Li SK (2012) Study of drug release and tablet characteristics of silicone adhesive matrix tablets. Euro J Pharm Biopharm. doi:10.1016/j.ejpb.2012.07.006

9. Lin SB, Durfee LD, Ekeland RA, McVie J, Schalau GK (2007) Recent advances in silicone pressuresensitive adhesives. J Adhes Sci Tech. doi:10.1163/156856107781192274

10. Mecham S, Sentman A, Sambasivam M (2010) Amphiphilic silicone copolymers for pressure siensitive adhesive applications. J Appl Polym Sci. doi:10.1002/app.31752

11. Czech Z, Kowalczyk A, Kabatc J, Shao L, Bai Y, Świderska J (2012) UV-initiated crosslinking of photoreactive acrylic pressure-sensitive adhesives using excimer-laser. Polym Bull. doi:10.1007/ s00289-012-0818-7

12. Antosik AK, Czech Z (2015) Wpływ ilości barwnika na fizyczne właściwości silikonowych klejów samoprzylepnych. Przem Chem. doi:10.15199/62.2015.1.3

13. Czech Z (2004) Development in the area of UV-crosslinkable solvent-based pressure-sensitive adhesives with excellent shrinkage resistance. Euro Polym J. doi:10.1016/j.eurpolymj.2004.05.012

14. Czech Z, Kowalczyk A, Kabatc J, Świderska J (2012) Photoreactive UV-crosslinkable solvent-free acrylic pressure-sensitive adhesives containing copolymerizable photoinitiators based on benzophenones. Euro Polym J. doi:10.1016/j.eurpolymj.2012.05.010

15. Czech Z, Kowalczyk A, Ortyl J, Świderska J (2013) Acrylic pressure-sensitive adhesives containing $\mathrm{SiO}_{2}$ nanoparticles. Polish J Chem Tech. doi:10.2478/pjet-2013-0003

16. Singh AK, Niyogi UK, Sabharwal S, Kowalczyk A, Czech Z Mehra DS (2013) Shrinkage studies in electron beam curable polyurethane pressure-sensitive adhesive. J Adhes Sci Tech. doi:10.1080/ 01694243.2012 .746160

17. Czech Z, Kowalczyk A, Sowa D, Kowalska J, Ragańska P (2013) Copolymerizable photoinitiators based on benzophenones and their influence on shrinkage of photoreactive acrylic PSAs. Inter Let Chem Phys Astr 8:49-56

18. Garcia-Castaneda C, Benavides R, Martinez-Pardo ME (2010) Crosslinking of rigid PVC by ionizing radiation to improve its thermal properties. Rad Phys Chem. doi:10.1016/j.radphyschem.2009.08.004

19. Matuana LM (2009) Rigid PVC/(layered silicate) nanocomposites produced through a novel meltblending approach. J Vin Add Tech. doi:10.1002/vnl.20183

20. Pimentel Real LE, Ferraria AM, Botelho do Rego AM (2008) Comparison of different photooxidation conditions of poly(vinyl chloride) for outdoor applications. Polym Test. doi:10.1016/j. polymertesting.2008.05.009

21. Sterky K, Hjertberg T, Jacobsen H (2009) Effect of montmorillonite treatment on the thermal stability of poly(vinyl chloride) nanocomposites. Polym Deg Stab. doi:10.1016/j.polymdegradstab. 2009.04.036

22. Strait CA, Tabor RL, Lancaster GM, U.S. (1990) Patent No. 07229078. Washington, D.C.: U.S. Patent and Trademark Office

23. Antosik AK, Ragańska P, Czech Z (2014) Termiczne sieciowanie samoprzylepnych klejów silikonowych nadtelenkami organicznymi. Polimery. doi:10.14314/polimery.2014.792 